\title{
Of Mushrooms and Method: History and the Family in Hobbes's Science of Politics
}

The standard view of Thomas Hobbes's political philosophy is that it is a form of contract theory. Commentators who disagree on much else nonetheless typically agree upon this. ${ }^{1}$ Deborah Baumgold, in particular, has recently argued that Hobbes's political theory is an attempt to combine the absolutist commitments of Jean Bodin with the contract approach of Hugo Grotius, inaugurating a contractualist tradition in political thought that runs through Locke and Rousseau all the way to Rawls. ${ }^{2}$ There are, however, compelling reasons for rejecting the standard view of Hobbes as a contract theorist. These are revealed by undertaking a close examination of Hobbes's account of the family and of the role of history. Doing so invites us to reconsider our assessment of how he believes that sovereignty, and thus political society, really comes into being, and what that means for the underlying status and foundation of Hobbes's political philosophy as a whole.

The following essay performs this task, aiming in particular to reverse the order of priority typically assigned to Hobbes's views of sovereignty by institution and acquisition. In addition to casting doubt on Hobbes's status as a contract theorist, two further consequences follow. First, we are discouraged from thinking of Hobbes as in any sense a foundationally democratic thinker. Second, the way to an alternative intellectual history of post-Hobbesian political thought is opened, one focusing upon history and the family in the context of arguments over human sociability rather than the traditional contract-orientated path with its much-trodden route through Locke and Rousseau. 
When setting out to discuss 'The right of Masters over slaves' in De Cive, Hobbes declared that his procedure would be 'To return once again to the natural state and to look at men as if they had just emerged from the earth like mushrooms and grown up without any obligation to each other'. ${ }^{3}$ By this stage Hobbes had already laid down one of three ways 'someone can have Dominion over the person of another': disparate individuals coming together and out of fear of each other agreeing to erect sovereign power to hold them all in awe. ${ }^{4}$ In the language of De Cive, this first method was 'commonwealth by design'; in Leviathan, 'commonwealth by institution'. 5 Yet there were two other ways political power could be erected. In Leviathan these were given as 'generation' and 'conquest', classed under the collective heading of 'commonwealth by acquisition'. (In the De Cive they were examples of 'natural commonwealth', as oppose to designed, 'political' ones). In the case of sovereignty by acquisition, men erected sovereign power not out of fear of each other indiscriminately, but out of fear of the superior force of a specific other who demanded submission. But in all other respects sovereignty was the same whether instituted or acquired.

The insistence that men be considered as like mushrooms was no arbitrary stipulation or minor expository device, nor was it an off-hand allusion to the Lucretian postulate that men had sprung fully-formed from the earth, offered in lieu of a working explanation of humanity's primordial origins. Rather, it was necessitated by several interlocking aspects of Hobbes's position. Hobbes was concerned to do without any appeal to patriarchalist theories which explained sovereign power in terms of the relations men bore to their fathers, drawing analogies between kings and their subjects, or tracing patrimonial 
descent from Adam. ${ }^{6}$ Aside from the sheer historical implausibility of the latter sort of account, Hobbes consistently maintained that sovereignty was necessarily founded in the consent of the ruled, and understood accordingly in purely natural terms. This emphasis on consent was not merely absent from, but actively denied by, patriarchal theories of sovereignty, making them anathema to Hobbes. ${ }^{7}$

Furthermore, Hobbes's deductive science of politics could have no use for appeals to historical or genetic accounts of sovereignty as founded in past relations. History for Hobbes was 'the register of knowledge of fact', and specifically 'the register we keep in books' ${ }^{8}$ But being merely the register of facts of experience, history could never provide infallible proof: 'Whatsoever examples may be drawn out of history', Hobbes declared, 'they are no arguments'..$^{9}$ As Leo Strauss noted some time ago, 'Hobbes...cannot rest content with such findings as to the historical origin of States, for they give no answer to the only important question, which concerns the right order of society'. ${ }^{10}$ History was no source of demonstration in arriving at certain truths, necessary for a proper political science of the sort Hobbes claimed to be putting forward, the findings of which (save the signaled and single exception of his preference for monarchy over aristocracy and democracy) he claimed as proved according to scientific deduction. ${ }^{11}$ Men had to be considered as mushrooms, because the rights and obligations they owed to each other, and the possibilities for associating they were thereby capable of, had to be wholly understandable, and fully accounted for, in a purely analytic framework without appeal to contingent historical or genetic factors known only by experience. Which is not to say that Hobbes lacked an account of how men had, in actual historical practice, arrived 
in the condition of political society. As we shall see he had a fully operational and integrated theory of how this had happened. The point is that history had to be supplementary to scientific demonstration of both why men needed to live in commonwealths to escape their natural condition, and what forms such an artificial association must take.

Third, and again connectedly, Hobbes's parallel conceptual commitments in his theoretical construction necessitated his considering man in this way. Human beings without collective power holding them in awe were ipso facto in their 'natural condition'. It did not matter whether man had always lived in a primitive pre-political state, having never experienced government, or if he had lost established political society due to civil war, thus putting him into a postpolitical state. In either case, how man got into such a condition was irrelevant to the science of demonstrating what must be done for him to exit it. Man was thus properly considered, in scientific terms, as like a mushroom having popped into existence.

Finally, there was no place in Hobbes's theory for speculative accounts of man's psychological development. According to Hobbes man was an animal 'not born fit for society'.12 The lack of a cosmopolitan world society indicated that when associating men do not look primarily for 'friendship', but for 'honour' and 'advantage'. Both these drives were thus natural, and in fact propelled men to try and form society, either in order to secure recognition and esteem in the eyes of peers, or for the utility gains on offer from group co-operation. But the problem with 'honour' was that it was necessarily positional: 'glorying, like honour, is nothing if everybody has it, since it consists in comparison and pre-eminence'. ${ }^{13}$ Honour undermined both itself and 'advantage', meaning that man was 
specifically an animal not born fit for large and lasting society. Hobbes's state of nature was characterized as containing 'confederacies', bands of marauding brigands, and - as we shall see, problematically - families. But nonetheless, Hobbes was committed to a static picture of human psychology. Bernard Mandeville, when expounding his alternative account of man as the 'the Prey and proper Food of a full grown Leviathan', would later agree with Hobbes that man was naturally unsociable due to the disruptiveness of honour (or more specifically, pride). ${ }^{14}$ But not sharing Hobbes's analytic commitments regarding the state of nature, or his conception of political theory as a deductive science, Mandeville offered a speculative conjectural history of man's psychologicalsocial evolution over great spans of time, during which man learned to live in society and experienced a remolding of his psychological capacities accordingly. ${ }^{15}$ Jean Jacques Rousseau, as Adam Smith would astutely recognise, would later follow Mandeville in the Second Discourse, making psychological change - in Rousseau's language, human 'perfectibility' - the engine of naturally unsociable man's gradual socialization. ${ }^{16}$ But Hobbes's a priori method excluded any possibility of a developmental - even less, a conjectural developmental account of how man came to learn to live in society.

Yet Hobbes by no means neglected the fact such human mushrooms both came into existence, and were sustained in their earliest years, in a very different manner to their fungal analogues. Human beings were everywhere born into, and raised in, families. If children were not cared for and nurtured outside of political society, humanity would not have survived long enough to exit its natural condition. Yet the existence of the family as a necessary feature of prepolitical human existence generated a serious problem for Hobbes. If human 
beings lived in families, and were able to form bonds of shared affection as well as reaping utilitarian benefits from such associations, how could they be said to be animals not born fit for society, able to form it only artificially?

Hobbes's solution was to render the family an expressly political institution. ${ }^{17}$ Whilst patriarchal theorists claimed that paternal authority was founded in the act of biological generation, Hobbes flatly denied this: 'they shew not, neither can I find out by what coherence, either generation inferreth dominion, or advantage of so much strength'.18 Authority was rightly founded in the protection that an overawing parent rendered unto a vulnerable child. Accordingly, where laws and custom were absent, and fatherhood could not be proven, mothers had dominion over children. Men acquired such dominion either by gaining dominion over the mother (and by logical transitivity, all that was hers), or by providing directly for the child and becoming its protector. Likewise, foster parents who rescued abandoned or orphaned offspring gained dominion over them, and could lose this to another only if the third party (be it the birthmother or not) took over the role of protector and provider. Fundamentally, therefore, on Hobbes's account dominion 'is not so derived from the Generation, as if therefore the Parent had Dominion over his Child because he begat him; but from the Childs Consent, either expresse, or by other sufficient arguments declared'. ${ }^{19}$ As always for Hobbes, the consent of the ruled was the ultimate foundation of political authority, rendered in exchange for protection on reciprocal condition of obedience.

Making this move allowed Hobbes to block the suggestion that the existence of families disproved his central claim that man was an animal not born fit for society. But it meant incurring a number of distinct costs. By making 
the family a political institution, Hobbes was forced to supply a stunted account of familial relations wholly excluding affective feeling and reducing the relationship to one of only power, protection, sustenance and obedience. Although this meshed well with Hobbes's vision of human competitors as emotionally isolated positional competitors, it reduced the overall plausibility of his already exceedingly narrow picture of human affective capacities.

Similarly, by making the family a political institution founded upon the consent of the child, Hobbes was forced to stretch his theory beyond breaking point. Gesturing towards the consent of the child as 'expresse' or by 'other sufficient arguments declared' could not hide the fact that in no plausible sense of consent - not even Hobbes's extremely expansive understanding of that term as compatible with the utmost extremities of fear and duress - could young children be said to consent to a parent's rule. Although it has been suggested that Hobbes can be rescued from this implausibility by claiming that children be understood as consenting to the rule of parents by back-projecting future adherence to the fourth law of nature demanding gratitude, this cannot be an adequate solution. ${ }^{20}$ For a start, back-projection of anticipated future adherence to the laws of nature is simply not the same thing as consent in the present instance. More fundamentally, in order for adherence to the laws of nature to be rational, an individual must have guarantees that such adherence will not expose them as prey - which means living under common power. But such power must be established if it is to count, and thus any consent derived from the fourth law of nature must assume the existence of sovereign power already, either making such consent redundant or rendering Hobbes's logic circular. Furthermore, Hobbes's emphasis on consent as the foundation of the political family was 
directly undercut by his own insistence that 'children, fools, and madmen that have no use of reason' cannot authorize others to represent them, and so cannot be personated other than by fiction (which itself requires the prior establishment of sovereign power under which fictional personification can be licensed, as with bridges, idols and figments). ${ }^{21}$

Even more fundamentally, by plugging one leak in his vessel Hobbes necessarily opened another. If men were always born into families, properly considered political institutions, how could it be said that man was ever in his allegedly 'natural condition', characterized by misery and war? In fact Hobbes was initially able to maintain the coherence of his account. On the one hand it was true that insofar as men were raised in families they were not properly in the state of nature as children, because always under the protection of a parent who was owed obedience. But on the other, Hobbes's central proposition that man was naturally unsociable always pertained to large and lasting society. Confederacies, tribes and families were constituent parts of the state of nature; indeed, were one of the things that made it so dangerous by facilitating the effective equality of all in attempts to kill. ${ }^{22}$ Children could be considered as not in the state of nature in the sense of benefiting from the protection afforded to them by their parents. But they nonetheless remained in the state of nature with regards to other families, as did all adults with regards to rival confederacies for defence and attack, and hence large and lasting society was not secured by the pre-political existence of the family, and man was properly considered naturally unsociable in the absence of overarching sovereign power.

The real difficulty in Hobbes's theory came in attempting to square the above with his central conceptual commitment to sovereign power as being 
necessarily founded on union. Essential to Hobbes's position was the proposition that sovereignty was an instance of pure artifice, founded not on natural affection, or uncoordinated attempts to secure honour or advantage, but by the disordered multitude of individuals being unified and given a singular will through an act of representation. Such was union - as opposed to mere concord a necessary condition of sovereignty proper. ${ }^{23}$ But if the family was truly a political institution, it must be a 'reall Unitie of them all', and therefore an instance of union. ${ }^{24}$ But such union was clearly incapable of establishing the security men sought in erecting commonwealths via the institution of an overarching absolute power, insofar as the family unit remained vulnerable to the ravages of outside groups, including other (larger and stronger) families. But if unable to provide protection the family could not be considered as establishing sovereign power, because a condition of such power was the capacity to provide protection under the public sword. Either the family was union without protection, thus falling short of the conditions of sovereignty, or it was mere concord and good for only small-scale association, and thus not truly political. In either case, the family constituted a point at which Hobbes could not reconcile his parallel insistences that true political power was characterized by union, and that a necessary condition of sovereignty was the ability to protect.

In the Elements and De Cive, Hobbes effectively skipped over this problem, claiming that "The same family if it grow by multiplication of children, either by generation or adoption; or of servants, either by generation, conquest, or voluntary submission, is to be so great and numerous, as in probability it may protect itself, then is that family called a PATRIMONIAL KINGDOM, or monarchy by acquisition'. ${ }^{25}$ As families expanded in size and were able to subdue and 
conquer others, affording protection to all who consented to the rule of the leading patriarch, they grew into monarchical commonwealths founded on conquest. Hobbes ignored the problematic question of what exactly the family's status was before it achieved the self-sufficiency and adequate size to ensure adequate defence for its members. In Leviathan, however, he noted the tension this generated:

By this it appears, that a great Family if it be not part of some Common-wealth, is of it self, as to the Rights of Soveraignty, a little Monarchy; whether that Family consist of a man and his children; or of a man and his servants; or of a man, and his children, and servants together: wherein the Father or Master is the Soveraign. But yet a Family is not properly a Common-wealth; unless it be of that power by its own number, or by other opportunities, as not to be subdued without the hazard of war. For where a number of men are manifestly too weak to defend themselves united, every one may use his own reason in time of danger, to save his own life, either by flight, or by submission to the enemy, as hee shall think best. ${ }^{26}$

If large enough to offer self-sufficient protection and exercise rights of sovereignty, a large family was properly considered a commonwealth. But if smaller than that - unable to self-sufficiently engage in the 'hazard of war' - the family could not be said to be a commonwealth. But if so, how could it nonetheless be said to be a properly political institution? These problems were endemic to Hobbes's position. Forced to make the family a political institution founded on consent to block its being used as a resource for claiming natural sociability, Hobbes opened up an unavoidable inconsistency with his account of what political power properly considered must be. ${ }^{27}$

Lurking alongside these problems is a more notorious question regarding the extent to which Hobbes considered his conception of man in his 'natural condition' a genuine historical proposition, as oppose to a purely theoretical 
device used to illustrate the necessity for sovereign power. ${ }^{28}$ In fact there are at least four relevant questions here, which must be carefully distinguished and separately addressed. First, there is the matter of whether Hobbes thinks man's natural condition is the same whether conceived of as a pre-political, or a postpolitical, condition. Second, does Hobbes think that man has ever existed in 'the state of meer Nature' in real historical experience? Third, is the natural condition that Hobbes describes in his most famous evocations - for example chapter 14 of Elements, and chapter 13 of Leviathan - intended to be a straight description of an actual, specific historical condition (one that was, we might say, located in a real time and place that could be identified accordingly)? Or is it an idealization of the general features of a specific sort of condition man could subsist within (that is, we might say, as an 'ideal type' which exemplifies the most important characteristics of a particular condition, even if no time or place has ever uniformly exhibited all these features completely or in their entirety)? Fourth, to what extent does Hobbes think that of the two methods for forming a commonwealth - institution or acquisition - both count as real historical or practicable ways in which commonwealths were or could be instituted, as oppose to analytic examinations of how they theoretically might be?

With regard to the first question the answer is clear and determined by the fundamental commitments of Hobbes's political theoretic method. Man without the artifice of sovereign power is ipso facto in his natural condition: there can be no significant conceptual difference in analyzing his pre- or postpolitical condition: 'during the time men live without a common Power to keep them all in awe, they are in that condition which is called Warre' - such war being ex hypothesi man's natural condition. 
The second question requires a more complex answer. On the one hand, Hobbes gives several indications that man has frequently existed in a state of nature at many times in his historical development in terms of a pre-political condition. The 'savage people in many places of America' are said to live so, with 'no government at all' excepting 'the government of small Families, the concord whereof dependeth on natural lust' (an instance, it is worth noting, of Hobbes revealing the inconsistencies between his accounts of the family and of political government). ${ }^{29}$ And although such a condition 'was never generally so, over the world', the point is that it has nonetheless often been so in many times and places. Similarly, and as regard the post-political condition, Hobbes clearly considers England during the civil war to have been such, Charles I having forfeited sovereign power when he lost the ability to protect his subjects due to the actions of the Parliamentary rebels. More fundamentally, Hobbes possessed a fully operative account of how, historically, men did come to live in commonwealths. As he put it in Leviathan when discussing the origins and functions of heraldry, 'Germany, being anciently, as all other countries in their beginnings, divided amongst an infinite number of little lords, or masters of families, that continually had wars one with another', it nonetheless eventually transitioned through cycles of conquest to modern kingship, 'when many such families, joined together, made a greater monarchy'. In A Dialogue between a Philosopher and a Student, Of the Common Laws of England Hobbes expressly stated that 'Great Monarchies have proceeded from small Families' following war, 'wherein the Victor not only enlarged his Territory, but also the number and riches of his Subjects'. In this 'manner, which is by War, grew up all the greatest Kingdoms in the World, viz. the Aegyptian, Assyrian, Persian and the Macedonian 
Monarchy; and so did the great kingdoms of England, France and Spain'. ${ }^{30}$ Similarly, Hobbes claimed in Behemoth that 'The Greeks had for a while their pettie Kings, and then by sedition came to be pettie Common-wealths; and then growing to be greater Common-wealths, by sedition againe became Monarchies'. ${ }^{31}$ This clearly indicates that Hobbes believed man to have originally existed in a pre-political state of nature, the exit from which was achieved by a historical process of conquest driven by the most successful warring patriarchal families. This was followed by specific historical variations in Greece and Italy, caused by dissatisfaction with monarchical rule, and yielding aristocratic and democratic regimes, as well as confused political theories of mixed sovereignty. Such experiments in rule eventually infected the political thought of North European states as they developed in the shadow of the classical tradition, something which had a greatly detrimental effect, and which Hobbes's science of politics was intended to reverse: 'There was never any thing so deerly bought' after all, 'as these Western parts have bought the learning of the Greek and Latine tongues'. ${ }^{32}$

As a consequence, Hobbes's analytic stylizations of the state of nature for example in Elements chapter 14 and Leviathan chapter 13 - are best thought of as conceptual idealisations rather than descriptions of specific times or places, or any actual condition that has simultaneously exhibited all the features Hobbes lists as characteristic of the state of nature. ${ }^{33}$ On the one hand, Hobbes's deductive conception of political theory debars him from making appeal to actual historical (and even less conjectural historical, as any appeal to man's primitive time before records were kept would have to be) experience to establish his political deductions. On the other, due to his being committed to 
treating the state of nature as conceptually identical in both pre- and postpolitical terms, his characterization of this condition is idealized in the political scientific works so as to cover both cases simultaneously, enabling the relevant deductions about the need for sovereign power to be made accordingly. In actual practice - be it pre- or post-political - a specific instance of the state of nature may not exhibit all of the features that Hobbes lists in (for example) Leviathan chapter 13, such as lack of industry, culture, navigation, trade, 'commodious Building', cartography, measuring of the passing of time, art, letters, or 'society' tout court. But insofar as there is an absence of sovereign power, there will be 'a continuall feare, and danger of violent death'. ${ }^{34}$ The state of nature will obtain, and Hobbes believes enough of the characteristics he elucidates as part of the natural condition of mankind will feature so as to make man's condition one of misery, with the solution necessarily being the erection of common overawing power. 35

Finally, and following directly from the above, I suggest that Hobbes's account of sovereignty by institution is best thought of not as a genuine historical proposition for how commonwealths ever have, or ever will, come into existence, but as an irenic device for reconciling men to the necessary conditions of political authority. ${ }^{36}$ There are several complementary reasons for adopting such an interpretation. First, sovereignty by institution is deeply implausible if understood as a practical proposition about how men might ever actually erect common power. If humans are as mutually suspicious and disposed to the seeking of positional superiority as Hobbes suggests, it is difficult to see how they will come to trust others sufficiently so as to assemble in one place long enough to make agreements, and why they would ever be content, or sufficiently 
trusting, to invest one individual - even when understood as a representative of their own wills, a complex idea it took Hobbes at least three substantial works of political philosophy to adequately elucidate - with unlimited power and superiority. Even more fundamentally, and again relating to the practicalities of sovereignty by institution, in order for the natural person (or persons) chosen to bear the artificial person of sovereignty to in fact truly be sovereign, he (or she, or they) must immediately exercise overwhelming coercive force over all others so as to be able to offer the protection that is a necessary condition of sovereign power. Yet how could any such public force be suddenly and immediately brought into existence, and brought to bear with sufficient efficacy so as to terrorize all potential defectors into conformity?

It will be no solution to say that in the founding moment all sovereigns are democratic. Not only should we note that Hobbes abandons this claim in Leviathan, we must also ask: what would guarantee that members of the new democratic sovereign - those, for example, who are in the minority after a majority vote (which Hobbes in De Cive stipulates as the necessary basis of democratic decision-making $)^{37}$ - would not immediately defect from their previous agreement and attack others, exposing the non-existence of the public sword necessary to keep them in awe and punishing them for their covenantbreaking? If the above objections apply only to a pre-political state of nature, the situation is certainly no better regarding a post-political one. In situations of civil war, new sovereigns are erected not by institution amongst equal parties mutually afraid of each other, but by the victory of the strongest leader whom losing parties submit to so as to avoid death. The end of civil war, on any plausible view of human conflict, is sovereignty by acquisition, not institution. 
In addition to these practical difficulties there are also conceptual problems in accounting for sovereignty by institution if understood as a real practical and historical proposition about the beginnings of political society. Hobbes in Behemoth states that 'the power of the mighty hath no foundation but in the opinion and belief of the people'. ${ }^{38}$ In order for sovereign power to be stable and successful, a sufficient majority of subjects must co-operate in its being preserved and upheld, i.e. by adhering to the laws on a daily basis and accepting the inconveniences that living under common power will necessarily impose. To this end, Hobbes in Leviathan insists that sovereigns provide not just a 'bare Preservation' but also all other 'Contentments of life, which every man by lawfull Industry, without danger, or hurt to the Common-wealth, shall acquire to himself'. Similarly, the rights of sovereignty 'cannot be maintained by any Civill Law, or terror of legall punishment' alone, and must instead be 'diligently, and truly taught' so that men knew and acknowledged the grounds of their obedience. ${ }^{39}$ Mass obedience to established political power is in large measure down to the disposition of the citizen body to obey, a disposition which must be so psychologically deep-rooted as to operate below the level of conscious reflection and daily decision-making. Although in times of crisis Hobbes seems to think that a work like Leviathan can remind individuals why they should obey, and even in times of peace should form part of the good education of subjects, it is difficult to see how sovereignty by institution as Hobbes presents it could acquire the deep-rooted disposition to obey ex nihilo (though admittedly this is less problematic with regard to post- as opposed to pre-political conceptions of the state of nature). ${ }^{40}$ With sovereignty by acquisition, however, the historical story of commonwealths developing over time out of families and through 
conquest provides the framework within which men could acquire the disposition to obey sovereign power whilst receiving the comforts of life under political authority, as well as the commodious benefits of peace. Thus unless we wish to charge Hobbes with having advanced the most implausible of elementary arguments against the background of a system of enormously elaborate sophistication and coherence, I suggest we take seriously the alternative: that sovereignty by institution is not meant as a serious practical proposition that has ever occurred, or ever will. ${ }^{41}$

As we have already seen Hobbes gives clear indication he thinks that, historically, all commonwealths emerged from generation and conquest. As well as the quotations supplied above, there is also Hobbes's suggestion that prior to his own conception of politics all commonwealths have had their foundations laid as though 'on the sand', something which his 'Rules' for the 'skill of making, and maintaining Common-wealths' are intended to correct. Given the complexity of sovereignty by institution, it is doubtful Hobbes considered anybody - either for want of 'leisure...the curiosity, or the method' - had been capable of achieving prior to his political works being published. ${ }^{42}$ These remarks, coupled with the implausibly of understanding sovereignty by institution as something that could ever actually have obtained in practice, strongly suggest that of the two ways in which a commonwealth may be formed, sovereignty by acquisition is how it always occurs in practice, with sovereignty by institution an analytic device used to examine the internal mechanisms of political authority and to illustrate the manner in which it is necessarily founded upon the consent of the ruled. ${ }^{43}$

This raises the question of why Hobbes emphasises sovereignty by institution, according it greater space for discussion in his works than 
sovereignty by acquisition. Several complementary answers are forthcoming. First, Hobbes is consistently clear that the rights of sovereigns do not change according to genesis: 'the Rights, and Consequences of Soveraignty, are the same in both'.44 All sovereignty is founded upon consent and out of fear, be it fear of each other indiscriminately, or of a specific other; at the point of a sword, or in the absence of imminent mortal danger. ${ }^{45}$ However, by first examining in detail the mechanism of sovereignty by institution, Hobbes can demonstrate that sovereignty by acquisition has the exact same basis in fear and consent as sovereignty by institution. Furthermore, not only does sovereignty by institution usefully illustrate the workings of sovereignty tout court, it can also help reconcile men to what they would otherwise be disposed to claim was compromised or illegitimate - i.e. giving consent at the point of a conqueror's sword - by showing them that their objections regarding the influence of fear are simply confused. By emphasizing the legitimate basis of all sovereignty via the model of institution, Hobbes presents the most pleasing face of his theory, by way of encouraging readers to accept what they might otherwise not be well disposed to, whilst gutting the language of consent and covenant of its previous association with democratic or monarchomach theory and putting it to the service of his own unique version of sovereign absolutism. ${ }^{46}$ None of which need marginalize the conceptual importance of institution in Hobbes's account: one major upshot of Hobbes's thought experiment is that by imagining sovereign power coming into being 'as if every man should say to every man' that he will suspend immediate exercise of the right of nature by erecting common power, this procedure simultaneously vindicates the authoritative character of that power - an authority, Hobbes's expansive understanding of consent is designed 
to show, which is equally conferred upon sovereigns by acquisition. ${ }^{47}$ As Kinch Hoekstra has demonstrated, Hobbes's philosophy is fundamentally conditioned by the guiding aim not of stating what he necessarily thinks is true, but of what he thinks will best promote peace, should the two diverge. ${ }^{48}$ Insofar as this was better served by concentrating on sovereignty by institution over acquisition, this was what Hobbes's commitment to provide a philosophy that supported established sovereign power demanded of him, and which he supplied - the emphasis on institution being precisely irenic, intended to promote peace.

The consequences of this evaluation are significant. For a start, it encourages us to abandon the standard - and it must be said, vague and usually unhelpful - classification of Hobbes as a 'contract' theorist. There is no contract in Hobbes's theory of sovereignty, only covenant, and such as by necessity cannot take place between a sovereign and a people (the latter of which indeed exists only when represented by the former). ${ }^{49}$ The most potent weapon in Hobbes's conceptual armoury is not contract, but consent. Yet Hobbes's understanding of consent is deliberately expansive, a point which takes on especial significance when coupled with the realisation that in practice all sovereignty will be established via acquisition, in which the role of consent is reduced to the actedupon desire not to be put to the sword. Hobbes remains a theorist of consent, albeit understood on his own expansive terms. But in light of the above it is hardly appropriate to think of him as a theorist of contract.

Baumgold has posed the question of who the 'real' Hobbes is: 'Is he better characterized as a philosophical contractarian, a historical contractarian, or an anti-foundational defender of the powers-that-be?'50 Baumgold's own answer is that Hobbes's commitment to a philosophical method of contractarian thought is 
undermined by a need to admit real historical experience, resulting in his being most consistently a contract thinker when he surreptitiously eschewed his own putative commitment to a deductive science of politics. In a similar vein, Richard Tuck has noted that there is a serious problem in accounting for what can motivate the first person to initiate a covenant to institute sovereignty in the state of nature, given the ipso facto absence of guarantees that others will reciprocate. Tuck claims that there is 'no easy answer' that can be 'extracted from the Hobbesian texts' regarding the question: 'how is the social contract possible?' Tuck settles instead for offering an account of promise-making in very general terms, with individuals calculating that covenanting will not leave them any worse off, even if they don't become better off, but which he confesses 'puts the matter in terms which Hobbes himself did not use, but it is arguably loyal to the general character of his idea'. ${ }^{51}$ I suggest instead that these sorts of tangles can be avoided, and Hobbes's coherence quite clearly stated and appreciated using his terms alone, if we abandon the unwarranted insistence that he is a contract theorist whilst ceasing to regard sovereignty by institution as a practical proposition about the origins of political society.

Second, scholarship that attempts to locate Hobbes as a foundational democratic thinker in the western political tradition is called into serious question. Most compellingly put forward by Richard Tuck, this thesis appeals to the De Cive's stipulation (repeated from the Elements) that all sovereigns are originally by necessity democratic, and only later become either aristocracies or monarchies. ${ }^{52}$ But it should be noted that this claim pertains exclusively to sovereignty by institution. If Hobbes does indeed think that in practice all sovereignty is by acquisition, then the notion of a democratic founding is part of 
a thought experiment to elucidate the mechanics of a concept, not a stipulation about the fundamental attributes of sovereignty. And we should further note that in Leviathan Hobbes abandons the notion of a democratic founding even in sovereignty by institution. The reason for this is plain: with the innovation of the concept of authorization, introduced in chapter 16 of Leviathan and with no precedent in the earlier works, even sovereignty by institution could be made to issue immediately in monarchy (or aristocracy), without the need for an intermediate period of democratic sovereignty to either institute monarchy, or put itself to sleep under the rule of a temporary kingship exercising administrative governmental powers rather than sovereignty proper. ${ }^{53}$ Hobbes, in other words, jettisoned the use of a democratic founding in his theory of sovereignty as soon as he could make do without it. It may remain the case that, via the influence of the De Cive on a European audience, Hobbes's ideas - as transmitted through Rousseau, and then the Abbe Sieyès - constitute a crucial part of the genealogy of the modern concept of democratic sovereignty. ${ }^{54}$ But that is a separate historical story, and one that must be told on its own terms. Hobbes was no believer in the fundamentally democratic basis of sovereignty. On the contrary, one of his main objectives was to neutralize and destroy such claims. ${ }^{55}$

Hobbes possessed a functioning and coherent account of how men not born fit for society nonetheless came historically to form commonwealths and achieve large and lasting society: via sovereignty by acquisition, initially by generation, then by conquest. Yet being historical (and necessarily in part conjectural) this account could form no part of Hobbes's science of politics, and thus was not appealed to in establishing the basis of his theory of sovereign 
authority. The 'condition of meer Nature' was to be understood as a real historical proposition (in both pre- and post-political senses), despite being analysed predominantly in ideal terms, whilst sovereignty by institution was an illustrative, irenic device for explaining the grounds of legitimate political authority and reconciling men to it accordingly.

With this revaluation of Hobbes's political theory in place we are invited to reconsider the history of political thought after Hobbes. In particular, we may turn away from the exceedingly well-trodden path of contractarian theory as typically traced through Locke and Rousseau, and towards an account focused upon history and the family as items in a longstanding debate over the human capacity to form large and lasting societies. Hobbes's subsequent critics would combine a reconceptualization of the family with a greater willingness to appeal to conjectural history in order to resist Hobbes's claim that man was naturally unsociable and required absolute sovereign power to render him otherwise. Anthony Cooper, Third Earl of Shaftesbury, and his later follower Francis Hutcheson, both denied Hobbes's central claim that positional honour-seeking was destabilising of human associations. ${ }^{56}$ Shaftesbury posited an elaborate teleology guaranteeing natural sociability, which Hutcheson later replaced with a mechanism of affective fellow feeling, 'sympathy', which ameliorated men's competitive urges and made them mutually tolerable in their psychological interactions. On both these accounts the family could be readmitted on common sense conceptions: as founded on natural affection and reciprocal furthering of utility. Such natural families provided the historical origin of early tribes, which through successful conquest and the increased furthering of material prosperity, grew into the earliest monarchies. That is, Shaftesbury and Hutcheson endorsed 
the same historical story as Hobbes - but reconfigured it on a foundation of natural sociability exemplified by the pre-political family, which in turn vindicated men's contemporary moral practices against what Shaftesbury and Hutcheson perceived to be Hobbes's moral scepticism.

Mandeville, by contrast, had no time for Shaftesbury's 'Wild Goose-Chase', agreeing with Hobbes that man was by nature not born fit for society. ${ }^{57}$ And although he did not share Hobbes's conceptual commitments regarding the necessary features of the state of nature in terms of absence of sovereign power, he agreed that the family was not the origin of large and lasting society. Rugged savages could control children only through terror and reward, but not teach them how to hide and redirect their pride so as to become mutually psychologically tolerable, the necessary condition of advanced social living. ${ }^{58}$ Men needed to have their pride redirected by political manipulation over time, erecting the artifice of large-scale society out of the selfish desire to augment both their material situation by rendering others safe and useful, and to secure mental esteem safely via non-violent status competition. Psychological evolution in a framework of conjectural pre-history, not the natural affection of the family, explained how naturally unsociable man came to live in society. It also enabled Mandeville to do away with the need for absolute sovereign power, licensing his own Whig politics on a foundation of natural unsociability, re-interpreted for the new world of opulent commercial societies.

Entering the debate over human sociability after all these figures - who he explicitly named in the introduction to the Treatise as having put the 'science of man' on a new footing 59 - David Hume's novel innovation was to reconceptualise the state of nature as an explicitly hypothetical device used only 
for analytical exposition, a 'mere philosophical fiction, which never had, and never could have any reality'.60 Hume agreed with Hutcheson that men's capacity for sympathy ameliorated competitive esteem seeking, and made them to that degree naturally sociable. ${ }^{61}$ Due to the pre-political existence of the family, "tis utterly impossible for men to remain any considerable time in that savage condition, which proceeds society; but that this very first state and situation may justly be esteem'd social'.62 However, uncoordinated pursuit of material goods rapidly led men into conflict and threatened to destabilize the relations of property required to achieve flourishing large and lasting society (something Hutcheson had sought explicitly to deny in his vociferous rejection of Pufendorf's sub-Hobbesian account of human sociability). ${ }^{63}$ Accordingly, the artificial virtue of justice had needed to be invented in order to regulate men's utility-seeing interactions and ensure the stability of possessions upon which large and lasting society was founded. In explaining the emergence of justice, Hume invoked the state of nature not as a genuine historical proposition but as an 'idle fiction' which 'yet deserves our attention, because nothing can more evidently show the origin' of artificial virtues like justice. ${ }^{64}$ By combining conjectural history with an explicit modeling of the state of nature as a purely analytic device, Hume was able to avoid the complications Hobbes had encountered with regards to the prepolitical existence of the family - something greatly furthered by his wholesale abandonment of the category of sovereignty, replacing this with natural authority as generated by the opinion of mankind. ${ }^{65}$

The theory of justice is the lynchpin of Hume's political theory. When placed in its proper eighteenth context, however, it is revealed as being fundamentally a theory of human sociability for large and lasting conditions. 
Hume's achievement was to steer a middle-route between the strong natural unsociability theories of Hobbes and Mandeville rooted in irreducibly competitive accounts of human psychology, and the countervailing assertions of Shaftesbury and Hutcheson that man was naturally sociable due to his essentially moral constitution. Hume rejected both these visions, instead locating man's capacity to form society in the coordinated seeking of private utility. In order to achieve this, however, Hume had needed to offer novel reconceptualizations of both the family and of the role of history in explaining man's capacity to form society, in particular by making the primitive family a resource for blocking Hobbes's and Mandeville's psychology of individual competitiveness, whilst analyzing the state of nature as a fiction and explicitly bracketing real history from the analytic examination of justice (and hence, sociability). Although he principally took these concerns over from Mandeville, Hutcheson, and Shaftesbury, all three of these authors were animated by the challenge set by Hobbes. Hume's own reconceptualizations were in turn transmitted forward to his subsequent Scottish readers and critics, and his theory of justice is properly regarded as central in the emergence of Scottish Enlightenment conjectural history through its influence, albeit in different ways, on both Adam Smith's Lectures on Jurisprudence, and Adam Ferguson's An Essay on the History of Civil Society.

Although necessarily a subject for further examination, what finally emerges is the suggestion that the genealogical origin of Scottish Enlightenment conjectural history, albeit one doubtless largely unrecognized by its main proponents, is Hobbes's theory of the family and of history in the context of conceiving of man as an animal not born fit for society. This may lack the 
glamour of a Whiggish history tracing the emergence of popular democratic rule back through a series of canonical texts in a 'contract' tradition, one increasingly emphasizing the sovereignty of the people and the accountability of their contractually-bound rulers. ${ }^{66}$ But we should remember that Whig histories are usually wrong (and wrong because they are Whig). And insofar as the Scottish thinkers of the eighteenth century were centrally concerned with the nature of, and prospects for, liberty under the auspices of the state as the central fact of political modernity, their concerns may turn out to be much the same as ours. ${ }^{67}$ If so, knowing the origin of their ideas may help us to make better sense of our own.

Acknowledgements: The comments and suggestions of Quentin Skinner, John Robertson, Sophie Smith, Chris Brooke, Ben Slingo, Clif Mark, and two anonymous reviewers all immeasurably improved this paper. I would also like to thank Richard North for his patience and support, and for making the publication process as smooth as possible.

Funding: This work was supported by The Arts and Humanities Research Council block grant, and the University of Cambridge Faculty of History Prince Consort \& Thirlwall Trust.

\footnotetext{
${ }^{1}$ Works as diverse as the following have all endorsed in some form the claim that Hobbes is a contract theorist: Jean Hampton (1986) Hobbes and the Social Contract Tradition. Cambridge: Cambridge University Press; David Gautier (1969) The Logic of 'Leviathan': The Moral and Political Theory of Thomas Hobbes; Ross Harrison (2002) Hobbes, Locke and Confusion's Masterpiece: An Examination of Seventeenth-Century Political Philosophy. Cambridge: Cambridge University Press; Richard Tuck (1989) Hobbes. Oxford: Oxford University Press; Howard Warrender (1957) The Political Philosophy of Hobbes: His Theory of Obligation. Oxford: Clarendon Press; Patrick Riley (1982) Will and Political Legitimacy: A Critical Exposition of Social Contract Theory in Hobbes, Locke, Rousseau, Kant and Hegel. Cambridge, MA: Harvard University Press, Jody S. Kraus (1994) The Limits of Hobbesian Contractarianism. Cambridge: Cambridge University Press; Mark E. Button (2008) Contract, Culture and Citizenship:

Transformative Liberalism from Hobbes to Rawls. University Park, PA: Pennsylvania State University Press. Hobbes's generally accepted status as a contract theorist is reflected in the titles of such collections as D Boucher and P. Kelly (ed) (1994) The Social Contract from Hobbes to Rawls. London: Routledge, and Christopher W. Morris (ed) (1998) The Social Contract Theorists: Critical Essays on Hobbes, Locke, and Rousseau. Oxford: Rowman and Littlefield.
} 
${ }^{2}$ See especially Deborah Baumgold (1993) 'Pacifying Politics: Resistance, Violence, and Accountability in Seventeenth-Century Contract Theory' Political Theory 21: 6-27; 'When Hobbes Needed History' in G.A.J. Rogers and T. Sorell (ed) (2000) Hobbes and History. Routledge: London and New York, pp. 25-43; (2005) 'Hobbes and Locke’s Contract Theories: Political Not Metaphysical' Critical Review of International Social and Political Theory 8: 289-308; (2009) 'Hobbesian Absolutism and the Paradox of Modern Contractarianism' European Journal of Political Theory 8: 207-228, all of which are reprinted in (2010) Contract Theory in its Historical Context. Leiden: Brill.

3 Thomas Hobbes; R. Tuck and M. Silverthorne (ed) (1998) On the Citizen. Cambridge: Cambridge University Press, p. 102. In what follows I draw on a wide range of Hobbes's texts to build my case. It has recently been argued by Noel Malcolm that Leviathan in particular represents something of a break with Hobbes's earlier works. This may be true in certain aspects (for example with regards to Hobbes's theory of psychology that underpins his politics), but with regards to the argument at hand I am, like Philip Pettit, more impressed by the continuity and unity of Hobbes's thought than any disjuncture. See Noel Malcolm, 'Introduction' in Thomas Hobbes; Noel Malcolm (ed) (2012) The Clarendon Edition of the Works of Thomas Hobbes, 3 Vols. Oxford: Oxford University Press, I, pp. 12-24; Philip Pettit (2008) Made with Words: Hobbes on Language, Mind, and Politics. Princeton, N.J.: Princeton University Press, p. 6.

${ }^{4}$ Hobbes (n. 3), p. 102.

${ }^{5}$ Hobbes (n. 3), p. 74; Thomas Hobbes (2012) The Clarendon Edition of the Works of Thomas Hobbes: Leviathan, N. Malcolm (ed) 3 Vols. Oxford: Oxford University Press, II, p. 262.

${ }^{6}$ This argument has been expanded in Gordon J. Schochet (1967) 'Thomas Hobbes on the Family and the State of Nature' Political Science Quarterly 82: 427-45.

7 On this see Quentin Skinner (2008) Hobbes and Republican Liberty. Cambridge:

Cambridge University Press, chapter 6.

8 Thomas Hobbes (1969) The Elements of Law, Natural and Politic, Ferdinand Tönnies (ed), second edition with introduction by M.M. Goldsmith. London: Frank Cass, p. 25. ${ }^{9}$ Hobbes (n. 5), III, p. 852. For a discussion of this, and Hobbes's conception of history more generally, see Karl Schuhmann, 'Hobbes's Concept of History' in G.A.J. Rogers and T. Sorell (ed) (2000) Hobbes and History. London: Routledge, pp. 3-24. See also J.G.A. Pocock, 'Time, History and Eschatology in the Thought of Thomas Hobbes' in (1971) Politics, Language and Time. London: Methuen \& Co., pp. 149-58; Baumgold (n. 2) 'When Hobbes Needed History', pp. 32-6, and 'Political not Metaphysical', pp. 294-6, regarding Hobbes's appeal to the Norman Conquest and historical instances of contractualist politics (although her reading differs significantly from that presented here).

${ }^{10}$ Leo Strauss (1936) The Political Philosophy of Hobbes: Its Basis and Its Genesis. Oxford: Oxford University Press, p. 103, cf. p. 104.

11 Hobbes (n. 3), p. 14.

12 Hobbes, (n. 3), p. 21.

${ }^{13}$ Hobbes, (n. 3), p. 24.

${ }^{14}$ Bernard Mandeville; F.B. Kaye (ed) (1988) The Fable of the Bees Vol. 1. Indianapolis, Liberty Fund, p. 355.

15 See especially Bernard Mandeville; F.B. Kaye (ed) (1988) The Fable of the Bees Volume 2. Indianapolis: Liberty Fund, dialogues 5-6.

${ }^{16}$ Smith, reviewing Rousseau's Second Discourse in 1756, claimed that 'Whoever reads this last work with attention, will observe, that the second volume of the Fable of the Bees has given occasion to the system of Mr. Rousseau, in whom however the principles of the English author are softened, improved, and embellished, and stript of all that tendency to corruption and licentiousness which has disgraced them in their original author'. Adam Smith, 'A Letter to the Authors of the Edinburgh Review', in W.P.D. Wightman, J.C. Bryce and I.S. Ross (ed) (1980) Glasgow Edition of the Works and 
Correspondence, Volume 3: Essays on Philosophical Subjects. Oxford, Oxford University Press, p. 250.

${ }^{17}$ For a discussion of this, and a useful overview of Hobbes's conception of the nature and role of the family both with and without sovereign power, see R.A. Chapman (1975) 'Leviathan Writ Small: Thomas Hobbes on the Family' American Political Science Review 69: 76-90. See also Philip Abbott (1981) 'The Three Families of Thomas Hobbes' Review of Politics 43: 242-58, and Richard Ashcraft (1971) 'Hobbes's Natural Man: A Study in Ideology Formation', Journal of Politics 33: 1076-1117, pp. 1098-1111.

${ }^{18}$ Hobbes (n. 8), p. 132.

${ }_{19}$ Hobbes, (n. 5), II, p. 308.

20 Schochet, (n. 6), p. 433-4.

${ }^{21}$ Hobbes, (n. 5), II, p. 248.

22 On the complexity of Hobbes's conception of natural equality in the state of nature, however, see Kinch Hoekstra, 'Hobbesian Equality', in S.A. Lloyd (ed) (2013) Hobbes Today: Insights for the 21 ${ }^{\text {st }}$ Century. Cambridge: Cambridge University Press, pp. 76-112. On families in the state of nature see Ashcraft (n. 17), pp. 1103-6.

${ }^{23}$ On the importance of the concord-union distinction see Istvan Hont (2005) Jealousy of Trade: International Competition and the Nation State in Historical Perspective. Harvard M.A.: Bellknap, pp. 20-2, 43-4. See also Richard Tuck, 'Hobbes and Democracy', in A. Brett and J. Tully (ed) (2006) Rethinking the Foundations of Modern Political Thought. Cambridge: Cambridge University Press, pp. 171-90; Isaac Nakhimovsky (2011) The Closed Commercial State: Perpetual Peace and Commercial Society from Rousseau to Fichte. Princeton N.J.: Princeton University Press, pp. 25-34; Ashcraft (n. 17), pp. 1102-4. ${ }^{24}$ Hobbes, (n. 5), II, p. 260.

25 Hobbes, (n. 8), p. 135.

${ }^{26}$ Hobbes, (n. 5), II, p. 314.

${ }^{27}$ As Hoekstra observes, 'Hobbes does not take a consistent position on this issue: sometimes he talks of families in the natural condition, sometimes he says that where there is familial authority there is no natural condition, and sometimes he says that a family is a commonwealth if and only if it is sufficiently large'. Kinch Hoekstra, 'Hobbes on the Natural Condition of Mankind', in P. Springborg (ed) (2007) The Cambridge Companion to Hobbes's Leviathan. Cambridge: Cambridge University Press, pp. 109-27, p. 118.

${ }^{28}$ For relevant discussions see William R. Lund (1988) "The Historical and "Political" Origins of Civil Society: Hobbes on Presumption and Certainty' History of Political Thought 9: 223-35; Warrender (n. 1), pp. 238-42; Sheldon Wolin (1961) Politics and Vision: Continuity and Innovation in Western Political Thought. London: George Allen \& Unwin, pp. 262-4; Richard Tuck (1999) The Rights of War and Peace: Political Thought and the International Order from Grotius to Kant. Oxford: Oxford University Press, chapters 4 and 7; Hoekstra (n. 27).

${ }^{29}$ Hobbes (n. 5), II, p. 194. For a discussion of how Hobbes's views of 'savage' peoples as outside of sovereign power, and thus exempt from the international law of nations, influenced subsequent European colonial attitudes, see Pat Maloney (2011) 'Hobbes, Savagery and International Anarchy' American Political Science Review 105: 189-204. 30 Thomas Hobbes; A. Cromartie (ed) (2005) The Clarendon Edition of the Works of Thomas Hobbes: A Dialogue Between a Philosopher And A Student, of the Common Laws of England. Oxford: Oxford University Press, p. 138. See also R.P. Kraynak (1983) 'Hobbes on Barbarism and Civilization' Journal of Politics 45: 86-109, which provides a summary of Hobbes's view of the progress of historical commonwealths from antiquity to the present.

31 Thomas Hobbes; P. Seaward (ed) (2010) The Clarendon Edition of the Works of Thomas Hobbes: Behemoth, or The Long Parliament. Oxford: Oxford University Press, p. 198. 
32 Hobbes, (n. 5), II, p. 334; cf. Kraynak (n. 30), pp. 689-702.

33 Cf. Strauss (n. 10), p. 104 on Hobbes's description of the state of nature as a principally idealized account, which nonetheless makes room for history.

${ }^{34}$ Hobbes (n. 5), II, p. 192.

35 Cf. Strauss (n. 10), pp. 102-4.

${ }^{36}$ I have developed the suggestion that Hobbes's conception of sovereignty by institution is best thought of as an irenic device from a remark of Hoekstra's. See Kinch Hoekstra (2006) 'The End of Philosophy (The Case of Hobbes)' Proceedings of the Aristotelian Society 106: 25-62, p. 60-1.

37 Hobbes (n. 3), p. 94.

${ }^{38}$ Hobbes (n. 31), p. 128. David Hume would later follows Hobbes in this observation, noting that 'Nothing appears more surprising...than the easiness with which the many are governed by the few'. Force is always on the side of the former, and the latter have 'nothing to support them but opinion'. David Hume (1985) 'Of the First Principles of Government', in Essays Moral, Political and Literary, E.F. Miller (ed). Indianapolis: Liberty Fund, p. 32.

${ }^{39}$ Hobbes (n. 5), II, pp. 520-2.

40 In this regard Hoekstra's remark that Hobbes compares sovereignty by institution in the Elements of Law 'to creation ex nihilo, which he regarded as incomprehensible' is particularly pertinent. Kinch Hoekstra, 'Hobbes and Democracy: A Lion in the House', in A. Brett and J. Tully (ed) (2006) Rethinking the Foundations of Modern Political Thought, pp. 191-218, p. 209.

${ }^{41}$ It might be suggested that 'institution' could still be the best way to describe individuals subjecting themselves to sovereign powers that already exist. This however is not the sense of sovereignty by institution in Hobbes's technical sense of the term, i.e. individuals of roughly equal power, meeting in a state of nature condition, and choosing one natural person to bear the artificial person of sovereign and thus instituting political society through mutual covenant. Self-subjection to established sovereign power is, on Hobbes's schema, more accurately thought of as a form of 'peaceful conquest', the motivation to submit being the securing of protection and/or the avoidance of prospective violent (and hence painful, and potentially lethal) subjugation.

42 Hobbes (n. 5), II, p. 322.

${ }^{43}$ Hobbes (n. 5), II, p. 312.

${ }^{44}$ Hobbes (n. 5), II, p. 306.

45 Hobbes (n. 3), p. 74.

${ }^{46}$ Again see Skinner (n. 7), chapter 6.

${ }^{47}$ Hobbes (n. 5), II, p. 260.

${ }^{48}$ See especially Kinch Hoekstra (n. 36), and (1997) 'Hobbes and the Foole' Political Theory 25: 620-54.

${ }^{49}$ Hobbes (n. 5), II, p. 204, p. 268. Contract pertains to the immediate mutual transfer of right, covenant takes place when at least one side delays the transfer to a future point. The erection of sovereign power is thus always, by necessity, an act of covenanting, not contract, and never between sovereign and subjects, but always between the 'natural persons' who wish to escape the state of nature by erecting an artificial person to bear sovereignty. For a discussion see M.M Goldsmith (1966) Hobbes's Science of Politics. New York, Columbia University Press, chapters 5-6.

${ }^{50}$ Baumgold (n. 2), 'When Hobbes Needed History', p. 36.

51 Tuck (n. 1), pp. 68-9.

52 Tuck (n. 23). See also Richard Tuck (forthcoming) The Sleeping Sovereign. Cambridge: Cambridge University Press. The view that Hobbes is a fundamentally democratic thinker, or at least initiates a tradition of thought that culminates in modern democratic (and frequently liberal democratic) thinking has also been put forward by Gianfranco Borrelli (1991) ‘Hobbes e la teoria moderna della democrazia. Rappresentanza assoluta 
e scambio politico' Trimestre 24: 243-63; Alexandre Matheron, 'The Theoretical function of democracy in Spinoza and Hobbes', in W. Montag and T. Stolze (ed) (1998) The New Spinoza. Minneapolis: University of Minnesota Press, pp. 207-18; Vickie B. Sullivan (2004) Machiavelli, Hobbes and the Formation of a Liberal Republicanism in England. Cambridge: Cambridge University Press; George Mace (1979) Locke, Hobbes, and the Federalist Papers: an Essay on the Genesis of American Political Heritage. Carbondale and Edwardsville: Southern Illinois University Press. For extended discussion of this matter, the argument of which the present paper is intended to support, see Hoekstra (n. 40), which notes that Tuck is followed in the supposition that for Hobbes any form of government begins by democratic election and that democracy is the fundamental political order, by George Croon Robertson, Ferdinand Tönnies, Leo Strauss, Manfred Riedel, Tito Magri, Glenn Burgess, Lucien Jaume and Karlfriedrich Herb, amongst others: p. 209, n. 82. I agree with Hoekstra that this is a misreading of Hobbes's position.

${ }^{53}$ For an overview see Quentin Skinner, 'Hobbes on Persons, Authors and Representatives', in P. Springborg (ed) (2007) The Cambridge Companion to Hobbes's Leviathan, pp. 157-80. Cambridge: Cambridge University Press; cf. Hoekstra (n. 40), pp. 212-3. For a different reading of Hobbes's abandonment of democratic founding in Leviathan, see Deborah Baumgold (2004) 'The Composition of Hobbes's Elements of Law' History of Political Thought 25: 16-32, pp. 17, 27-8.

${ }^{54}$ For an exposition of such an account, see Hont (n. 23), 'Introduction'. See also Michael Sonenscher (2007) Before the Deluge: Public Debt, Inequality and the Intellectual Origins of the French Revolution. Princeton N.J.: Princeton University Press.

55 For the most comprehensive refutation of the view of Hobbes as a fundamentally democratic thinker, see Hoekstra (n. 40).

56 Anthony Ashley Cooper, Third Earl of Shaftesbury (2001) Characteristicks of Men, Manners, Opinions, Times, D.J.D. Uyl (ed), 3 Vols. Indianapolis: Liberty Fund, II, pp. 17481; Francis Hutcheson, 'On the Natural Sociability of Mankind', in J Moore and M. Silverthorne (ed) (2006) Logic, Metaphysics, and the Natural Sociability of Mankind. Indianapolis: Liberty Fund, 2006.

57 Mandeville (n. 14), p. 331.

58 Mandeville (n. 15), dialogue 5. For an overview, see E.J. Hundert (1994) The

Enlightenment's Fable: Bernard Mandeville and the Discovery of Society. Cambridge, Cambridge University Press, pp. 62-75.

59 David Hume; D.F. Norton and M.J. Norton (ed) (2007) A Treatise of Human Nature, 2 Vols. Oxford: Oxford University Press, I, p. 5.

${ }^{60}$ Hume (n. 59), I, p. 317.

${ }^{61}$ Hume (n. 59), I, pp. 234-5.

62 Hume (n. 59), I, p. 316.

63 For a more detailed account see Paul Sagar (2013) 'Self-Love, Luxury and Sympathy:

The Case of Archibald Campbell' History of European Ideas 39: 791-814, pp. 22-3.

${ }^{64}$ Hume (n. 59), p. 317.

${ }^{65}$ See Istvan Hont, 'Commercial Society and Political Theory in the Eighteenth Century: The Problem of Authority in David Hume and Adam Smith', in W. Melching and W.

Velema (ed) (1994) Main Trends in Cultural History: Ten Essays, pp. 54-94. Amsterdam: Rodopi.

${ }^{66}$ Indeed in the case of Rousseau there is evidence for thinking that he set himself up as a contract theorist precisely because he believed that Hobbes wasn't one, and that was Hobbes's fundamental failing. See for example Jean Jacques Rousseau; V. Gourevitch (ed) (1997) The Discourses and Other Early Political Writings. Cambridge: Cambridge University Press, pp. 174-5; Jean Jacques Rousseau; V. Gourevitch (ed) (1997) The Social Contract and Other Later Political Writings. Cambridge: Cambridge University Press, pp. 41-9. 
${ }^{67}$ For discussions see Duncan Forbes (1975) Hume's Philosophical Politics. Cambridge: Cambridge University Press; Istvan Hont, 'Adam Smith's History of Law and Government as Political Theory', in R. Bourke and R. Geuss (ed) (2009) Political Judgement: Essays for John Dunn, pp. 131-171. Cambridge: Cambridge University Press; Iain McDaniel (2013) Adam Ferguson in the Scottish Enlightenment: The Roman Past and Europe's Future. Cambridge M.A.: Harvard University Press. 